\title{
Thermal Properties
}

\author{
L. C. Myers
}

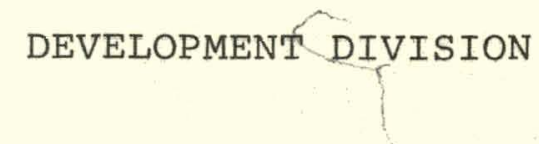

APRIL - JUNE 1975

SANL NO. 363-004

For

Lawronce Livermore Laboratory]

Livermore, California

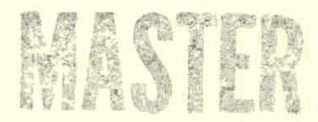




\section{DISCLAIMER}

This report was prepared as an account of work sponsored by an agency of the United States Government. Neither the United States Government nor any agency Thereof, nor any of their employees, makes any warranty, express or implied, or assumes any legal liability or responsibility for the accuracy, completeness, or usefulness of any information, apparatus, product, or process disclosed, or represents that its use would not infringe privately owned rights. Reference herein to any specific commercial product, process, or service by trade name, trademark, manufacturer, or otherwise does not necessarily constitute or imply its endorsement, recommendation, or favoring by the United States Government or any agency thereof. The views and opinions of authors expressed herein do not necessarily state or reflect those of the United States Government or any agency thereof. 


\section{DISCLAIMER}

Portions of this document may be illegible in electronic image products. Images are produced from the best available original document. 


\section{NOTICE}

This report was prepared as an account of work sponsored by the United States Government. Neither the United States nor the United States Energy Research and Development Administration, nor their employees, nor any of their contractors, subcontractors, or their employees, makes any warranty, express or implied, or assumes any legal liability or responsibility for the accuracy, completeness or usefulness of any information, apparatus, product or process disclosed, or represents that its use would not infringe privately-owned rights. 


\title{
Thermal Properties
}

\author{
L. C. Myers
}

DEVELOPMENT DIVISION

This repon was preparice

Sponsored by the Prepared as an account
the United States United States
Research and States

their ench and Developm the United

subcontractors, or, not any of thinition, nor anergy
warramiy,

liability or express of implied employees, contraclors,

or usefulness of ansibility for the ar assumes any any

infringe disclosed, or information, acuracy, complet legal

-

use would not

April - June 1975

SANL No. 363-004

$A-1$ 


\section{ABSTRACT}

Chemical reactivity test data are reported which indicate a correlation between the volume of gas evolved by PBX 9404 and (1) the sample holder, (2) the order in which the samples are run and/or the position the samples are conditioned in the oil bath. Runs were al so made on samples. that were immersed 63.5 and $76.2 \mathrm{~mm}$ into the bath.

Thermal decomposition data are given for PETN which show its reaction mechanism to be dependent on temperature and/or the extent of the reaction. Activation energies of 6000 and 980 joule/mole (22 and 4 $\mathrm{kcal} / \mathrm{mole}$ ) were calculated from the data.

\section{DISCUSSION}

\section{INVESTIGATION OF THE VARIABLES IN THE CHEMICAL REACTIVITY TEST DATA}

The investigation into the source of the variations in the chemical reactivity test has continued this quarter. Previously, it has been shown that (1) a one degree change in the temperature would cause a. $9 \%$ change in the volume of gas evolved from PBX 9404, (2). small variation in the weight of the PBX 9404 . would have caused only very small variations in the total gas evolved, and (3) a change in the immersion depth from 50.8 to $76.2 \mathrm{~mm}$ depth of the sample holder in the oil bath would cause a significant variation in total gas evolved.

If chemical reactivity samples of $\mathrm{PBX} 9404$ are conditioned in an oven (complete immersion), the samples evolved about the same amount of gas as a sample immersed $76.2 \mathrm{~mm}$ in the $0 i 1$ bath. Therefore; a preliminary test was made this quarter to compare data from samples immersed $63.5 \mathrm{~mm}$ to those immersed $76.2 \mathrm{~mm}$. These data are given in Table I, but only two samples immersed $63.5 \mathrm{~mm}$ were run and these had such a large variation in the total gas evolved $(0.352$ to $380 \mathrm{ml})$ that no conclusion can be made. It will be necessary to make additional runs next quarter.

Another series of tests was run using the same sample holders, but varying the order in which they were run. Run No. 1 was the first run of the day and the sample was located in the front of the oil bath. Run No. 2 was the second and it was located in the $0 i 1$ bath just behind No. 1. Table II lists the data from the same sample holders in the order of increasing total gas volumes minus the nitrogen a. With only one exception (sample holder No. 16 Run No. 4) the gas volume increases with run number indicating a possible correlation between the sample holder, run number and/or position in the oil bath with the volume of gas evolved from the sample.

\footnotetext{
Nitrogen was excluded from the total gas evolved to reduce the variations caused by smali air leaks.
} 
Table I. Chemical Reactivity Test Data for PBX 9404

(Gas Volumes in me at STP)

$(0.250 \mathrm{~g}$ Conditioned at $120 \mathrm{C}$ for $22 \mathrm{hrs})$

$\underline{\mathrm{N}_{2}} \quad \mathrm{CO} \quad \mathrm{NO} \quad \mathrm{CO}_{2} \quad \mathrm{~N}_{2} \mathrm{O}$ Total

$76.2 \mathrm{~mm}$ Immersion Depth

$\begin{array}{llllll}0.017 & 0.032 & 0.195 & 0.115 & 0.014 & 0.372\end{array}$

$\begin{array}{llllll}0.015 & 0.031 & 0.194 & 0.116 & 0.015 & 0.371\end{array}$

$\begin{array}{llllll}0.015 & 0.033 & 0.207 & 0.122 & 0.015 & 0.387\end{array}$

$\begin{array}{llllll}0.019 & 0.034 & 0.200 & 0.118 & 0.015 & 0.387\end{array}$

$63.5 \mathrm{~mm}$ Immersion Depth

$\begin{array}{llllll}0.014 & 0.030 & 0.188 & 0.107 & 0.013 & 0.352 \\ 0.010 & 0.031 & 0.200 & 0.123 & 0.015 & 0.380\end{array}$


Table II. Chemical Reactivity Test Data for PBX 9404

(Gas Volume in me at STP)

( $0.250 \mathrm{~g}$ Conditioned at $120 \mathrm{C}$ for 22 Hours)

\begin{tabular}{|c|c|c|c|c|c|c|c|c|c|c|}
\hline $\begin{array}{c}\text { Sample } \\
\text { Holder } \\
\text { No. } \\
\end{array}$ & $\begin{array}{c}\text { Run } \\
\text { Order } \\
\text { No. } \\
\end{array}$ & $\mathrm{N}_{2}$ & $\mathrm{CO}$ & NO & $\mathrm{CO}_{2}$ & $\mathrm{~N}_{2} \mathrm{O}$ & Total & $\begin{array}{l}\text { Total } \\
-\mathrm{N}_{2} \\
\end{array}$ & $\begin{array}{c}\begin{array}{c}\text { Mean } \\
\text { of Total } \\
-\mathrm{N}_{2} \\
\end{array} \\
\end{array}$ & $\sigma$ \\
\hline $\begin{array}{l}13 \\
13 \\
13 \\
13\end{array}$ & $\begin{array}{l}1 \\
1 \\
6 \\
6\end{array}$ & $\begin{array}{l}0.024 \\
0.022 \\
0.019 \\
0.039\end{array}$ & $\begin{array}{l}0.035 \\
0.032 \\
0.034 \\
0.037\end{array}$ & $\begin{array}{l}0.190 \\
0.192 \\
0.200 \\
0.201\end{array}$ & $\begin{array}{l}0.118 \\
0.121 \\
0.120 \\
0.124\end{array}$ & $\begin{array}{l}0.015 \\
0.015 \\
0.015 \\
0.015\end{array}$ & $\begin{array}{l}0.381 \\
0.382 \\
0.387 \\
0.415\end{array}$ & $\begin{array}{l}0.357 \\
0.360 \\
0.368 \\
0.378\end{array}$ & 0.366 & 0.009 \\
\hline $\begin{array}{l}14 \\
14 \\
14\end{array}$ & $\begin{array}{l}2 \\
2 \\
5\end{array}$ & $\begin{array}{l}0.019 \\
0.055 \\
0.017\end{array}$ & $\begin{array}{l}0.032 \\
0.032 \\
0.034\end{array}$ & $\begin{array}{l}0.189 \\
0.190 \\
0.203\end{array}$ & $\begin{array}{l}0.122 \\
0.135 \\
0.127\end{array}$ & $\begin{array}{l}0.015 \\
0.016 \\
0.016\end{array}$ & $\begin{array}{l}0.377 \\
0.429 \\
0.397\end{array}$ & $\begin{array}{l}0.358 \\
0.374 \\
0.380\end{array}$ & 0.371 & 0.011 \\
\hline $\begin{array}{l}15 \\
15 \\
15\end{array}$ & $\begin{array}{l}3 \\
3 \\
4\end{array}$ & $\begin{array}{l}0.011 \\
0.011 \\
0.013\end{array}$ & $\begin{array}{l}0.030 \\
0.033 \\
0.033\end{array}$ & $\begin{array}{l}0.191 \\
0.191 \\
0.200\end{array}$ & $\begin{array}{l}0.125 \\
0.124 \\
0.132\end{array}$ & $\begin{array}{l}0.016 \\
0.016 \\
0.017\end{array}$ & $\begin{array}{l}0.372 \\
0.376 \\
0.400\end{array}$ & $\begin{array}{l}0.361 \\
0.365 \\
0.387\end{array}$ & 0.368 & 0.009 \\
\hline $\begin{array}{l}16 \\
16 \\
16\end{array}$ & $\begin{array}{l}4 \\
3 \\
4\end{array}$ & $\begin{array}{l}0.024 \\
0.023 \\
0.019\end{array}$ & $\begin{array}{l}0.030 \\
0.034 \\
0.035\end{array}$ & $\begin{array}{l}0.184 \\
0.188 \\
0.193\end{array}$ & $\begin{array}{l}0.116 \\
0.114 \\
0.119\end{array}$ & $\begin{array}{l}0.015 \\
0.015 \\
0.016\end{array}$ & $\begin{array}{l}0.368 \\
0.374 \\
=0.381\end{array}$ & $\begin{array}{l}0.344 \\
0.351 \\
0.362\end{array}$ & 0.352 & 0.009 \\
\hline $\begin{array}{l}17 \\
17 \\
17\end{array}$ & $\begin{array}{l}2 \\
5 \\
5\end{array}$ & $\begin{array}{l}0.017 \\
0.025 \\
0.017\end{array}$ & $\begin{array}{l}0.032 \\
-0.031 \\
0.035\end{array}$ & $\begin{array}{l}0.194 \\
0.187 \\
0.199\end{array}$ & $\begin{array}{l}0.112 \\
0.114 \\
0.120\end{array}$ & $\begin{array}{l}0.014 \\
0.015 \\
0.015\end{array}$ & $\begin{array}{l}0.369 \\
0.377 \\
0.387\end{array}$ & $\begin{array}{l}0.352 \\
0.352 \\
0.370\end{array}$ & 0.358 & 0.010 \\
\hline $\begin{array}{l}18 \\
18 \\
18 \\
18\end{array}$ & $\begin{array}{l}1 \\
1 \\
6 \\
6\end{array}$ & $\begin{array}{l}0.017 \\
0.019 \\
0.015 \\
0.018\end{array}$ & $\begin{array}{l}0.032 \\
0.032 \\
0.037 \\
0.034\end{array}$ & $\begin{array}{l}0.195 \\
0.193 \\
0.200 \\
0.200\end{array}$ & $\begin{array}{l}0.115 \\
0.118 \\
0.118 \\
0.124\end{array}$ & $\begin{array}{l}0.014 \\
0.015 \\
0.015 \\
0.016\end{array}$ & $\begin{array}{l}0.372 \\
0.376 \\
0.385 \\
0.39 .2\end{array}$ & $\begin{array}{l}0.355 \\
0.357 \\
0.370 \\
0.374\end{array}$ & 0.364 & $\begin{array}{c}0.009 \\
\vdots\end{array}$ \\
\hline $\begin{array}{l}\text { Mean } \\
\text { Std. De }\end{array}$ & & & & & & & $\begin{array}{l}0.385 \\
0.015\end{array}$ & $\begin{array}{l}0.364 \\
0.011\end{array}$ & & \\
\hline
\end{tabular}


All of the runs given in Table II were made over a seven day period and the mean and standard deviation for the total volume of gas and the total volume of gas minus the nitrogen are $0.385 \pm 0.015$ and $0.364 \pm$ 0.011 , respectively.

If the data from sample holders 13 and 18 are compared, then the run order number is the more significant variable. As can be seen in Table III, the mean and standard deviation for the total gas evolved minus the nitrogen from Run No. 1 and No. 6 are $0.357 \pm 0.002$ and $0.373 \pm 0.004$ me, respectively, indicating that the run number and/or position has a greater effect on the variation in the gas evolved than the particular sample holder.

Three possible sources of variation are:

1. Variations in the instrumentation during the day such as the condition of the column or the sensitivity of the detector, etc.

2. Variation in the temperature of the $0 i 1$ bath with time, or a temperature gradient in the oil bath.

3. Difference in the sample holders.

Some preliminary runs were made on a third series of tests which will be completed next quarter. In this test series, the position of the sample in the oil bath and the run number were changed from that used in the series described previously. These data are given in Table IV for two sets of runs made 21 days apart $b$. The variation between run No. 1 and No. 6 has been eliminated; the reason for the variation remains unknown.

The tests to date indicate that a better temperature controlled oil bath would help to reduce the variations in the chemical reactivity test data.

\section{THERMAL DECOMPOSITION OF PETN}

Last quarter a limited amount of data were reported indicating that the thermal decomposition mechanism of PETN is dependent on temperature and/or the cxtent of the reaction. Additional data collected this quarter continue to indicate this dependency.

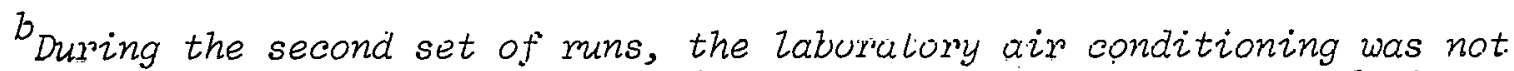
working and the temperature varied from a low of $24 \mathrm{C}$ to $32 \mathrm{C}$ during the day and this may have cuused the second set of mins to haire a larger volume of gas evolved. 
Table III. Chemical Reactivity Test Data for PBX 9404

(Gas Volumes in me at STP)

(0.250 g Conditioned at $120 \mathrm{C}$ for 22 Hours)

\begin{tabular}{|c|c|c|c|c|c|c|c|c|c|c|}
\hline $\begin{array}{l}\text { Sample } \\
\text { Holder } \\
\text { No. } \\
\end{array}$ & $\begin{array}{c}\text { Run } \\
\text { Order } \\
\text { No. }\end{array}$ & $\mathrm{N}_{2}$ & $\mathrm{CO}$ & NO & $\mathrm{CO}_{2}$ & $\mathrm{~N}_{2} \mathrm{O}$ & Total & $\begin{array}{l}\text { Total } \\
-\mathrm{N}_{2} \\
\end{array}$ & $\begin{array}{c}\text { Mean } \\
\text { of Total } \\
-N_{2} \\
\end{array}$ & $\sigma$ \\
\hline 13 & 1 & 0.022 & 0.032 & 0.192 & 0.121 & 0.015 & 0.382 & 0.360 & \multirow{4}{*}{0.357} & \multirow{4}{*}{0.002} \\
\hline 13 & 1 & 0.024 & 0.035 & 0.190 & 0.118 & 0.015 & 0.381 & 0.357 & & \\
\hline 18 & 1 & 0.019 & 0.032 & 0.193 & 0.118 & 0.015 & 0.376 & 0.357 & & \\
\hline $18^{\prime}$ & 1 & 0.017 & 0.032 & 0.195 & 0.115 & 0.014 & 0.372 & 0.355 & & \\
\hline 18 & 6 & 0.018 & 0.034 & 0.200 & 0.124 & 0.016 & 0.392 & 0.374 & \multirow{4}{*}{0.373} & \multirow{4}{*}{0.00} \\
\hline 13 & 6 & 0.039 & 0.037 & 0.201 & 0.124 & 0.015 & 0.415 & 0.378 & & \\
\hline 18 & 6 & 0.015 & 0.037 & 0.200 & 0.118 & 0.015 & 0.385 & 0.370 & & \\
\hline 13 & 6 & 0.019 & 0.034 & 0.200 & 0.120 & 0.015 & 0.387 & 0.368 & & \\
\hline
\end{tabular}


Table IV. Chemical Reactivity Test Data for PBX 9404

(Gas Volume in me at STP)

(C.250 g Samples Ccnditioned at $120 \mathrm{C}$ for 22 Hours)

\begin{tabular}{|c|c|c|c|c|c|c|c|c|}
\hline $\begin{array}{l}\text { Run } \\
\text { No. }\end{array}$ & Date & $\begin{array}{l}\text { Pcsition } \\
\text { ir. Bath }\end{array}$ & $\mathrm{N}$ & $\mathrm{CO}$ & NO & $\mathrm{CO}$ & $\mathrm{N}_{2} \mathrm{O}$ & Total \\
\hline 1 & $06 / 1 i / 75$ & Eack & 0.019 & 0.033 & 0.196 & 0.121 & 0.015 & $0.384^{\circ}$ \\
\hline 6 & $06 / 1: / 75$ & Front & 0.010 & 0.032 & 0.199 & 0.122 & 0.015 & 0.378 \\
\hline 1 & $07 / 08 / 75$ & Back & 0.016 & 0.036 & 0.209 & 0.131 & 0.016 & 0.408 \\
\hline 6 & $07 / 08 / 75$ & Front & 0.014 & 0.035 & 0.209 & 0.132 & 0.016 & 0.406 \\
\hline
\end{tabular}


The reaction rate can be represented by,

$$
d C / d t=A e^{-E / R T} C^{n} \text {. }
$$

where $C$ is the extent of the reaction at time $t$ and temperature $T, A$ is. the pre-exponeritial factor, $E$ is the activation energy and $n$ is the degree of the reaction. Equation (1) reduces to

$$
\int \mathrm{dC} / \mathrm{C}^{\mathrm{n}}=\left(\mathrm{Ae^{E/RT }}\right) t+\text { constant }
$$

If the extent of the reaction is constant, then $\int \mathrm{dC} / \mathrm{C}^{n}=f(C)=$ constant and equation (2) can be simplified to

$$
\text { ln } t=E / R(1 / T)+\text { constant. }
$$

The activation energy can be determined from the slope of the plot of the $\log$ of time as a function of $1 / T$ for given extents of reaction.

The data collected to date are given in Table $V$, and Figs. 1 and 2 are plots of the total volume of gas evolved as a function of time. From these graphs the time for given extents of reaction were determined. Fig. 3 is a graph of the $\log$ time as a function of $1 / T$ for given extents of reaction. The data produce a family of curves, rather than straight lines, indicating that the apparent activation energy is changing with temperature. The activation energy, calculated from two different parts of the curve $A$ and $B$, were 6000 and 980 joule/mole (22 and $4 \mathrm{kcal} / \mathrm{mole}$ ), respectively.

In addition to the dependency of the reaction mechanism on time and/or temperature, other data have previously been presented which indicate that the rate of decomposition is also particle size dependent.

The major interest in the thermal decomposition of PETN is below $100 \mathrm{C}$, and since the sample holders used are subject to leak over long periods of time, all glass sample holders with break seals are being acquired for the low temperature, long time runs.

\section{FUTURE WORK, COMMENTS, CONCLUSIONS}

Previously the investigation into the variations in the chemical reactivity test data have shown that small variations in the temperature of the oil bath used to condition the samplers and the depth the samples are immersed into the oil bath were the major sources of variation in the volume of gas evolved from PBX 9404.

Tests made this quarter show a correlation between the volume of gas evolved, the sample holder, and the order in which the samples are run and/or their position in the oil bath. Additional tests are planned to determine the degree of variation each of the above parameters produce. 
Table V. Chemical Reactivity Test Data for PETN

(Gas Volume in me Corrected to STP)

$$
\text { (0.250 g Samples) }
$$

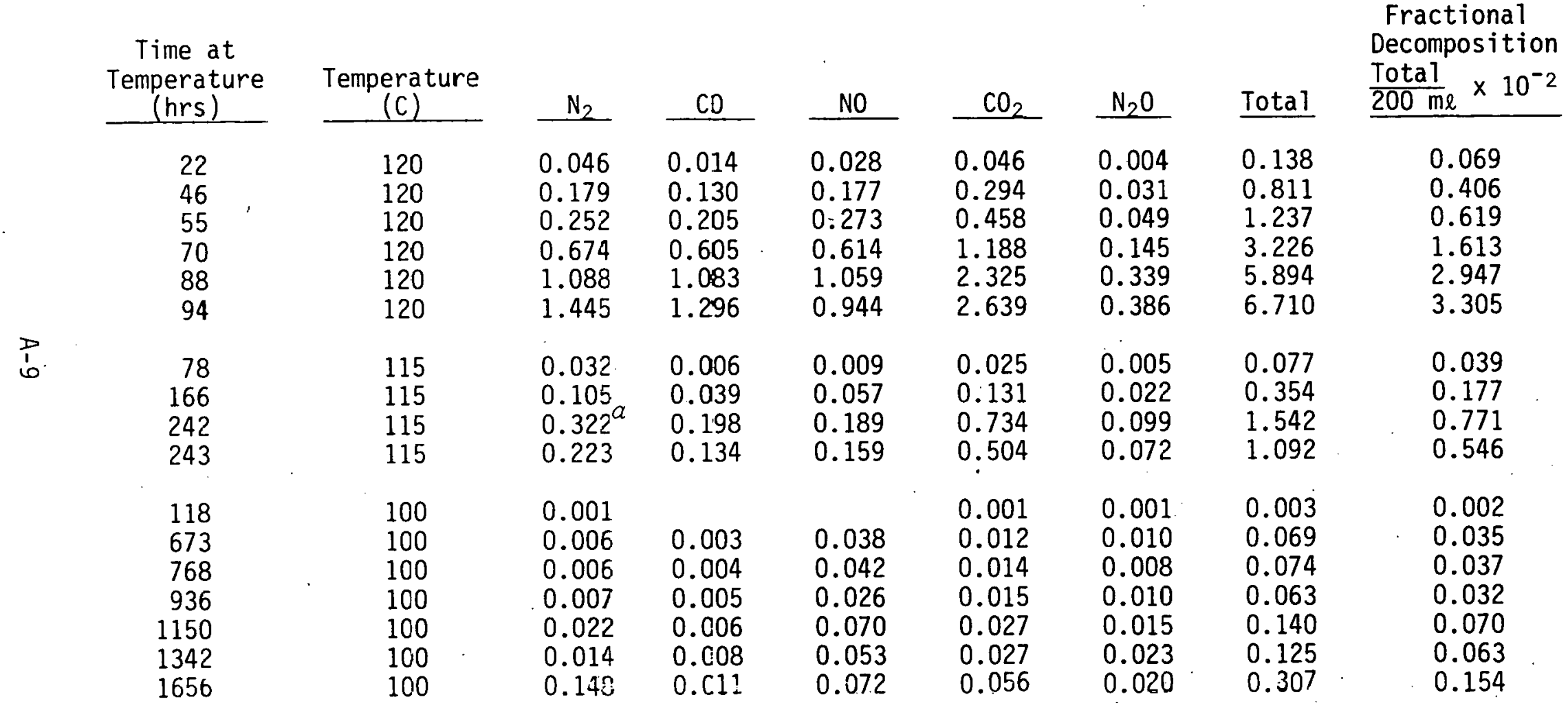




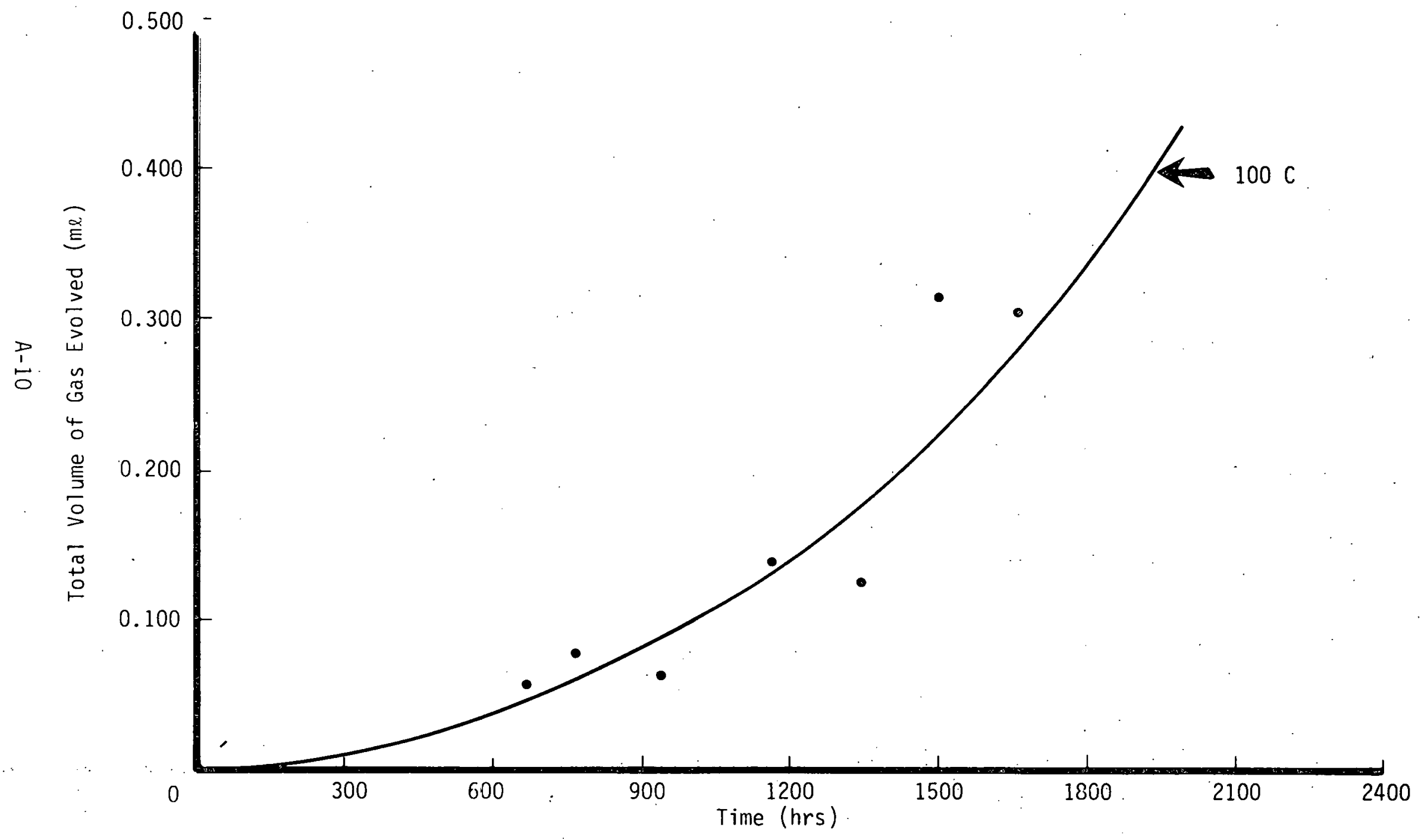

Fig. 1. Total Gas Evolved from PETN as a Function of Time 


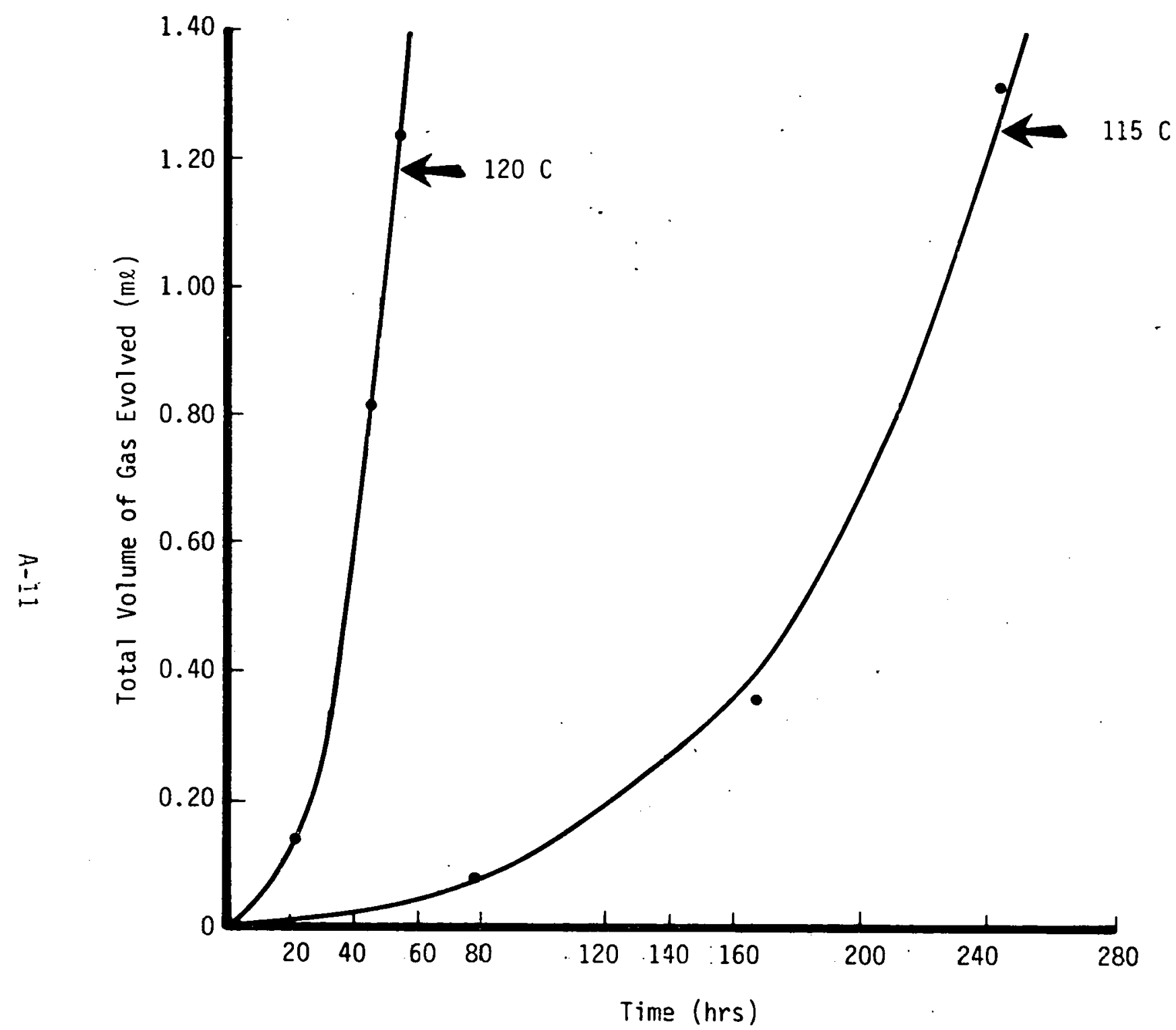

Fig. 2. Total Gas Evolved from PETN as a Function of Time 


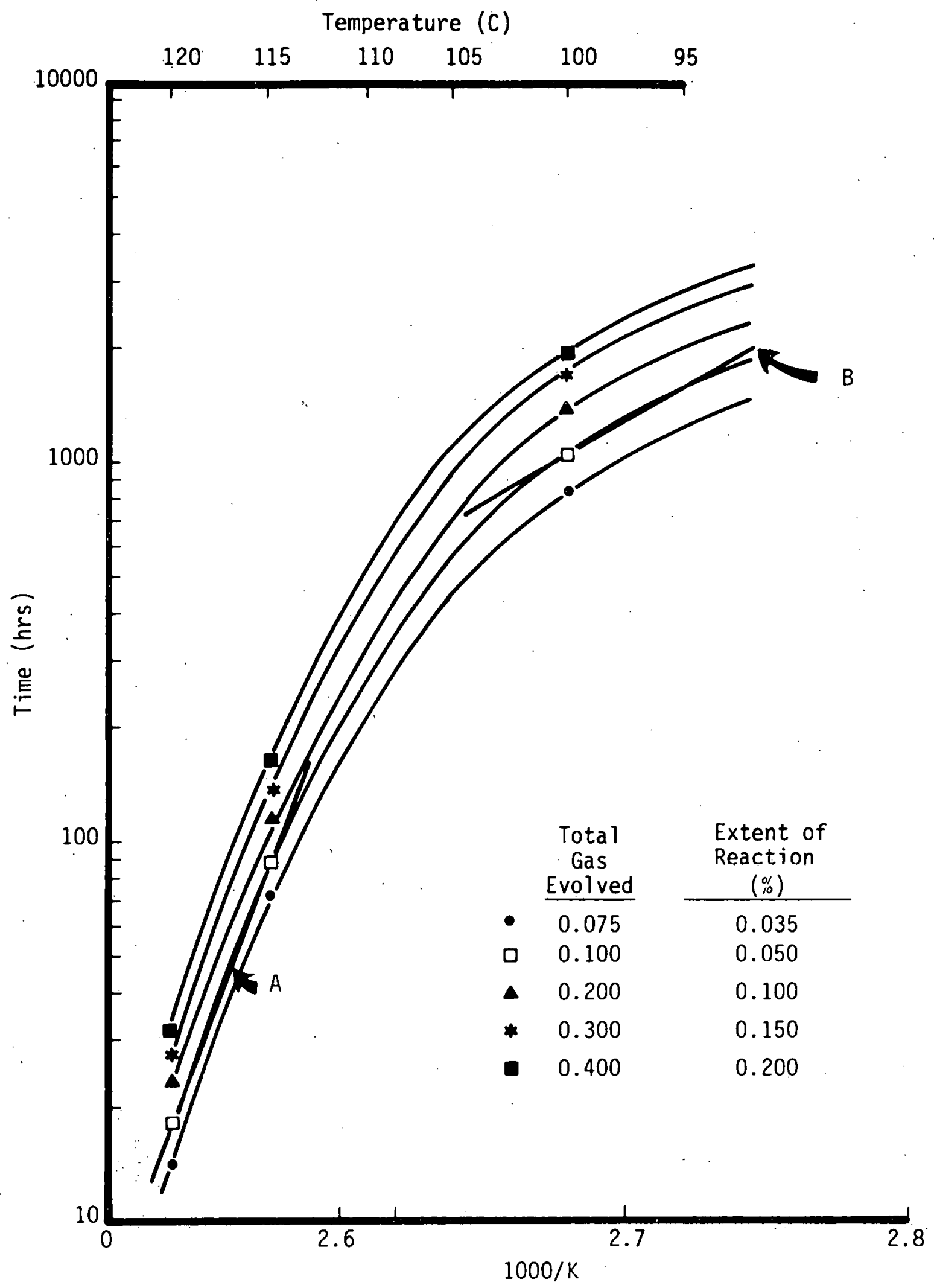

Fig. 3. Log of Time as a Function of the Reciprocal of the Absolute Temperature for Various Extent of Reaction of PETN 
The investigation into the thermal decomposition of PETN was continued this quarter, and the data continue to indicate that the reaction mechanism is temperature and/or extent of reaction dependent.

Because of the leaks encountered with the chemical reactivity test's sample holders, it will be necessary to use another type of sample holder to investigate the decomposition below $100 \mathrm{C}$. Therefore, glass sample holders with break seals will be used to obtain data at $100 \mathrm{C}$ and below. 